\title{
EU enlargement: Does economics of regional integration matter? ${ }^{* 1}$
}

\author{
Srđan Marinković ${ }^{2}$, Zenaida Šabotic ${ }^{3}$, Dragić Bankovic ${ }^{4}$
}

\begin{abstract}
For stability and advance of the EU and prospective member countries, it is important to assess the best time for new enlargement. In this paper, we have tested a number of macroeconomic and macro-financial variables in order to check whether a number of countries were ready to join the EU, and whether the candidates are ready. Some variables present criteria of nominal convergence as defined in Maastricht Treaty, while the rest of variables indicate the level of real convergence. Univariate analysis has indicated that the membership in the EU is significantly affected by GDP per capita, general government final consumption expenditure, final consumption expenditure, gross capital formation, gross national expenditure, and inflation. Following the univariate binary logistic analysis and separation of variables that affect the individual membership in the EU, a multivariate regression analysis was applied. Multivariate binary logistic regression confirmed significance of general government final consumption expenditure and gross capital formation. The analysis indicated the importance of selecting the timing of accession in terms of the achieved economic development, expressed through the selected macroeconomic indicators. Moreover, it appears that the list of tested economic criteria was played at best a secondary importance in past European enlargements.
\end{abstract}

Key words: macroeconomic indicators, European Union, regional integration, convergence criteria

JEL classification: F15, F16, F45, G15

\footnotetext{
Received: 02-05-2018; accepted: 17-12-2018

1 The authors are grateful to the Republic of Serbia Ministry of Education, Science and Technological Development for the funds and support that made this research possible (OI 179015; OI 179066).

${ }^{2}$ Full Professor, University of Niš, Faculty of Economics, Trg kralja Aleksandra Ujedinitelja 11, 18000 Niš, Serbia. Scientific affiliation: banking and finance, international finance, macroeconomics. Phone: +38162216068.E-mail: srdjan.marinkovic@eknfak.ni.ac.rs.

3 Teaching Assistant, State University of Novi Pazar, Department of Economic Sciences, Vuka Karadžića bb, 36300 Novi Pazar, Serbia. Scientific affiliation: statistics and econometrics, finance. Phone: +38120337669. E-mail: zenaida.sabotic@gmail.com.

${ }^{4}$ Full Professor, State University of Novi Pazar, Department of Mathematical Sciences, Vuka Karadžića bb, 36300 Novi Pazar, Serbia. Scientific affiliation: theoretical and applied matematics. Phone: +38120337669. E-mail:dragic.bankovic@gmail.com.
} 


\section{Introduction}

The first step for candidate countries to join the European Union (EU) is determined by several criteria of which only one is clearly economic in its nature. Namely, prospective new members should prove their ability to sustain competitive pressures within the EU in the systemic framework that would not give protection that goes beyond the institutions acceptable for a fully-fledged market economy. The other two elements concern political criteria (stable institutions that guarantee democracy, rule of law, human rights, and the protection of minorities), and adherence to the aims of political, economic and monetary union (adopting acquis communautaire, the complete framework of the EU legislation). Interestingly, even the last line of Copenhagen criteria for accession contains institutional elements that demand from candidates to have already remarkable achievements in terms of liberalisation, monetary and fiscal discipline. Just to mention, acquis communautaire includes free capital account (capital flows should be restriction-free not only within the EU but also vis-à-vis third countries), central bank independence, and no monetary support of government finances. Therefore, for accession countries it is strongly advisable to use a pre-preparatory phase to accomplish their transition or advance economic development before the very entry into the EU.

In this paper, we test the hypothesis that past EU enlargements were economically driven, and if it is so, which economic indicators are able to best explain accession success. For that, we have tested a number of macroeconomic and macro-financial variables in order to check whether some countries were ready to join the EU, as well as, when the candidates will be ready to do so. The analysis includes 40 countries, 28 EU members (the analysis includes Great Britain, because the data cover the period 2000-2014) and 12 countries that were not members. Some variables present criteria of nominal convergence, as defined in Maastricht Treaty, while the rest of variables indicate the level of real convergence. We know from the very persuasive 'gravity model' of international trade that trade between a pair of countries is proportional to their economic strength ('mass') and inversely proportional to the distance between them (alike to force of gravity in Newtonian physics). Knowing that bilateral trade is a function of national income, and that national income may explain the way that foreign direct investment (FDI) and other forms of capital and labour move within the integrated area, we expect that gross domestic product (GDP) as a proxy for national income, plays a significant role in explaining perspective gains from integration. Namely, GDP is one of the best fitted synthetic indicators of economic strength, able to capture many dimensions of prosperity and development of nations. However, we have added a dozen other variables, of which the majority is suggested by the economics of regional integration.

The rest of the paper is structured as follows: in the second section, we firstly give some remarks on the contemporary theory's stance in matters of economics of regional integration, then review empirical literature on various effects that fully- 
fledged integration of goods, services, capital and labour markets may have on countries that merge into a common market, and finally give economic rationale for the chosen data set, by reviewing the matter of nominal and real convergence between units that integrate. Section three explains data set and employed research methodology, while section four discusses the main findings. Consequently, the last section concludes.

\section{Literature review}

Strictly theoretically, economic or welfare gains from forming a regional integration can be divided into three lines: allocation, accumulation and location (Baldwin and Venables, 1995). Allocation effects are static in their nature and assume perfect competition. Factor endowments are considered unchanged. A decrease or a complete removal of trade barriers (trade costs) within the integrated area makes the trade between members less costly, boosts the trade and output within the area. The positive net welfare coming from this increase is attributable to trade creation effect. However, since this effect is initiated by discriminatory trade liberalisation, it may also harm the interest of non-member countries, as well as member countries. Trade diversion comes as a consequence of removal or tariffs decreasing in trade between two regions which favours trade between those regions on the expense of third region lowest-cost supplier which is now prohibited by existing tariffs. The effects of trade diversion on the integrated import countries' welfare may be ultimately negative. Besides negative effects borne by importing country, trade diversion also damages global allocation of resources. It moves allocation of production away from one directed by comparative advantage principle. Note that trade creation benefits depend on the assumption that resources are fully employed. If this holds, the lower cost imports will replace inefficient domestic production in domestic consumption and consumer gains will exceed production loses (plus government tariff revenue loss). However, if less efficient imports from the member country replace the more efficient (cheaper) import from rest of the world, domestic prices will not converge to the world prices, and the overall welfare effect will be negative. According to theory (Matthews, 2003: 18) "net effects of trade creation and trade diversion, which fully reflect allocation type of welfare outcome of trade integration, should be positive if the integration takes place between comparably developed economies, with complementary (rather than competitive) economic structures, and economies that already reached high level of mutual trade".

Accumulation (dynamic) effects demand different assumption about the nature of competition. Those effects are based on new trade theory (Krugman, 1980). If the competition was imperfect because of the pre-existing trade barriers, lifting the barriers will bring new opportunities but also new challenges on producers. An access to a larger (common) market allows producers to take advantage of 
economies of scale, to undergo specialisation of production and motivate them to reduce costs of production and increase quality of products in order to endure increased competition. From the side of consumers there is preference for variety, and large varieties of the same industry products are easier to trade within the integrated trade area.

Location effects are especially important if two regions that are significantly different in economic size and strength are merged. Those effects are more likely for more advanced integrations that also imply free movement of production factors (labour, capital etc.) beside free movement of goods and services. Though one can expect that capital moves toward the areas where it is scarce and labour is cheap, it is also possible that labour migrates toward the places where the capital is abundant and jobs are available at higher wages. It may in fact amplify differences in markets sizes, since producers tend to locate production capacities close to large markets, while at the same time, the decision to locate production there in turn increases market size, by increasing demand for intermediate and final products, the regularity known as circular causality (Baldwin, 1997). Then, there is a chance that all mobile factors will agglomerate or concentrate around a few central locations. Because of the potential location effects, a regional integration becomes a sensitive political question. If at the end of the day, a periphery may become even more distant from the core in terms of economic development, then the overall welfare implications of regional integration for less developed peripheral countries are questionable.

The EU presents the most completed type of regional integration. Besides removal of tariffs (as well as non-tariff barriers) for trade between members (free trade union), and unified trade and tariffs policy for the rest of the world (customs union) it allows free movement of economic factors along with free movement of goods and services (well-known four freedoms), so it belongs to 'common market type' of regional integration agreements.

Calculating costs and benefits of an integration process is all but an easy process. Fortunately, at least identification of types of costs and benefits may be completed since the economic theory has some answers on it. According to the theory of regional economic integration (Baldwin and Venables, 1995), there are to be several benefits of the integration: i) savings on costs related to trade, e.g. tariffs; ii) beneficial effects of forming single (larger) market that will bring more competition and improved efficiency, and iii) easier movement of factors of production, like foreign direct investments and labour in opposite direction. If integration is followed by institutional financial support of incumbent to new member countries, as it is the case with the EU, the budgetary transfers should also be considered. Of course, those transfers are distributional and do not change the position of the whole. An assessment of benefits of new member states that would come from financial transfer demands a careful scenario analysis. Making inferences and drawing conclusions simply based on recent history of enlargements 
(other countries' experience) may be misleading. Since transfers are benefits of new member states and adequate costs that are to be borne by old member states, old member states that are in charge for making (revising) rules can act on accommodative way (Kandogan, 2000; Csaba, 2001). It is exactly what happened with the Treaty of Nice (Heinemann, 2003). Hopefully, economic gains that are expected to come from new enlargements are well above direct transfers from the EU budget. The highest on the list are benefits of a larger (single) market free of tariffs that could boost trade within the EU. Moreover, some benefits are expected from capital movements and labour migration, together with budgetary transfer that would go from incumbent countries toward new members (Neueder, 2003).

\subsection{Empirical evidence on costs and benefits of integration}

There are variety of models and calculations used for assessing economic effects of such a unification project. The main challenge is to cover all possible effects and to express net effect using a single measure. Most often researchers use GDP trajectories to measure effects, but there are other equally comprehensive approaches. For example, Kohler (2004) used welfare effects instead of GDP figures, and made assessment for each country separately, starting from the assumption that a common enlargement shock may have different effects on both incumbent and new member states, depending on their specific economic structure. This justifies looking at enlargement as it is an exogenous shock that would lead to asymmetric disturbances across the EU. According to a comprehensive ex ante assessment (Breuss, 2002) of effects that the so called fifth enlargements may have on the existing and new member states, a group of new member states was expected to gain around ten times more from the enlargement than the incumbent countries. It was estimated that the distribution of gains will be directed according to the size of economies and strength of economic ties. It is also stressed that the absorption/ merging of such an inhomogeneous group of countries brings some risks, i.e. it may postpone business cycle synchronisation across the EU.

It is not easy to comprehensively formulate trade consequences of a regional integration. Firstly, there has to be already discussed conventional effects of trade creation vs. trade diversion. Secondly, the trade effect of unification depends on business cycles synchronisation. If economic activity moves in the direction opposite to that of the main trade partners, current account imbalance might have a depressive effect on trade flows (Maurel, 2004). Trade intensity between countries (or regions) has direct influence on their business cycles synchronicity, which is per se a factor that justifies regional integration. However, though the influence must be there, the nature of this influence seems to be case specific. More trade between countries (regions) may lead either to less synchronised business cycles, in case of specialisation of countries exporters motivated to take advantage of comparative advantage, or exactly opposite, more synchronised, if the business shocks are 
monetary or trade is largely intra-industry type. Moreover, historically, the impact has been more like the letter one (Rose, 2000). Finally, it seems that other aspects of integration, e.g. monetary integration, may also exert some effects on trade. More advanced type of regional integration that also includes integrated monetary affairs may account for some extra benefits in trades within the integrated area. However, evidence is mixed. In a seminal paper, Rose (2000) proved empirically that trade between countries that share the same currency tend to be several times higher that between countries that retain separate legal tenders. The result was robust even after controlling the effect of exchange rate volatility on trade. It may mean that a common currency area is a way more effective solution than currency peg policy option. The author believes that a part of this effect results from adapting of common currency is far more "serious and durable commitment than a fixed rate" (Rose, 2000: 9). A common currency prevents beggar-thy-neighbour policy of competitive devaluation that potentially may destroy the achieved trade integration. Casual empiricism supports the above argumentation. We would say that the recent Greek shock on the EMU showed that the exit from the monetary union is extremely complicated, both economically and politically. Moreover, wellevidenced 'home bias', i.e. strong propensity to trade within the country (currency area) relative to trade out of the country, can be at least partly explained by the common currency effect.

Empirical evidence on the above effects is as mixed as the prognostics based on the international trade theory. For example, Nahius (2004) simulation based on the gravity model of foreign trade gave estimate of two digit increase of internal EU market, mostly based on reduction of tariffs and non-tariff barriers. The countries that are assessed to take most benefits in that manner were Austria, Germany and Greece. The model also indicates that accession countries will likely gain more benefits than old member states. The trade increase is also concentrated around agriculture and some industries. Curran and Zignano's (2012) research, based on extensive data set on volume and structures of trade, not only supports the hypothesis that formal integration of two regions will bring more intense trade between the regions, but also reveals the fact that countries of fifth enlargement significantly increased their mutual trade without breaking the trade relationships with outside countries. However, not all empirical studies justify optimism. For instance, Maurel (2004) questioned any trade creation effect in case of some earlier enlargements, e.g. when Austria, Sweden and Finland entered the EU. Similarly, running the same estimation procedure as in Rose (2000), the author found weak effect of currency union on trade increase.

According to neoclassical growth model, providing that capital is mobile, i.e. no restriction is applied to cross-country movements, the capital is expected to flow out of capital abundant more developed economies into capital-scarce countries. The driving force is the law of diminishing returns that implies that 
marginal productivity of capital in the latter economies exceeds the same in the former economies (Buch, 1999). This process will eventually lead to equalisation of marginal return and increase of welfare in both capital exporting and capital receiving countries. In that analytical framework, regional integration is seen as a case of capital flow liberalisation. In a dynamic general equilibrium model based on neoclassical intellectual tradition, Garmel et al. (2008) found welfare effects of increasing capital flows between incumbent and new members rather large, persistent and mostly attributable to the model-specific elimination of costs related to managing and monitoring cross-border investments (therefore original term 'border-costs'). Although, in this study, effects are defined in monetary terms, as cost reduction or elimination, merely for the sake of elegance of the model, there are many benefits or conveniences that go with doing business in the same legal and regulatory environment, above all, access to large market, and externally supported devotion to politically stable and progressive market economy. If we add factor endowment (skilled labour etc.) and available structural funds, it is then clear that new EU member states are likely to draw capital for their investments more easily both from the EU and the rest of the world than a non-EU country, ceteris paribus. It was the fact in previous EU enlargements that many accession countries have taken steps toward capital market integration years before their actual year of EU entry. Thus, a rational market player may foresee successful enlargements and behave anticipatory. This is why effects of integration would develop gradually, over a period of time, with some appearing already at first sign that membership is granted (anticipatory) and some even after the formal accession (prolonged or ex post effects).

However, the evidence provided by Buch (1999) does not suggest that EU membership has had a significant impact on the accession countries to draw on foreign savings. The author assessed how close the dynamics of savings is to that of investments, running the procedure for a group of old members (South European countries) and new entrants. It appeared unlikely that membership alone may be attributed to capital account openness, but at the same time, it seems that the membership may influence the structure of capital flows. Buch and Piazolo (2001) have shown that not only capital-oriented measures, e.g. international bank claims, portfolio investments and FDI, but also trade developments, share a number of common determinants. Regarding all different types of capital inflow, as well as trade, GDP per capita (taken to be a proxy of host economy's state of development and market size) appears to be a significant variable. Thus, the benefits that a country may expect from launching the process of regional integration, as well as the membership effect itself, regarding the increase in trade and different types of capital inflow depends on the level of its market size and the state of development of the host economy, inter alia. The empirical research also gives some clue about the origin of those benefits. Buch and Piazolo (2001) found the integration beneficial especially for foreign direct investments, since it reduces uncertainty about perspective business conditions. Therefore, it appears that a sort 
of 'credibility effects' explains at least a part of positive effects that the integration may have on both trade and capital (FDI) dynamics.

Further on, it appears that not only FDI is responsive to the increase of 'credibility' but also capital markets. Dvořák and Podpiera (2006) tested the so-called entry announcement effect on the stock markets of accession countries and found that a large percent of a dramatic rise in local stock prices can be attributed to the repricing systemic risk. Therefore, integration effects can be rather significant in terms of their impact on temporary revaluation of local financial assets.

By applying the same economic logic, one would expect that regional integration brings equalisation of factor prices, and that it might also hold for labour. The region with abundant labour (higher level of unemployment, lower unit labour costs) will take position of a labour sending region and the region with abundant capital (labour deficient one) will be receiving labour, providing that trade liberalisation has not already removed incentives for such labour migrations. Such a labour movement across the regions will contribute to income and wages convergence. It does not have to happen if industry is imperfectly competitive, and if there are described location effects, which are empirically proven (Crozet and Koenig Soubeyran, 2004). Industry agglomeration will do exactly the opposite, that is, the divergence of wages between the regions. However, raised wages in the agglomeration relative to that of periphery (above certain level), providing that trade (transport) costs are less relevant, has a potential of reversing the trend, bringing about industry decentralisation, which limits further wage divergence (Hildebrandt and Wörz, 2005).

At the same time, unit labour costs, or wages, represent a decisive factor of paramount importance in shaping attractiveness of a country for inward FDI, and competitiveness in the common market (Belke and Hebler, 2000). Thus, if FDI moves from one to another region, based on differences in unit labour costs; it will diminish incentives for labour to move in the opposite direction. However, in reality both movements will probably take place at the same time.

Some previous estimates (Breuss, 2002; Kohler, 2004) were prone to assign welfare losses to accession countries based on anticipated labour migrations from Central and Eastern to Western Europe. Joining the EU for countries that entered fifth enlargement, meant migration of labour with some effects on wage level, especially for more mobile young working population. According to some recent studies (Elsner, 2013), lifting restriction on labour migration within the EU contributed to a new wave of emigration that accounts for six to nine percent decrease of workforce in Latvia, Lithuania, Poland and Slovakia. Consequently, the movement of labour contributed to wage increase among most mobile young population in home countries.

Last but not least, regional integration may be also seen as a productivity shock with potential effects on efficiency. It is not an issue frequently studied as trade 
and productive factors developments, but there is some research. Halkos and Tzeremes (2009) by using DEA window analysis found the countries of Eastern Europe increase their economic efficiency relative to the old Europe in the period that surrounds their EU entry, although the outcomes were far from homogenous for both group of countries. The countries that compete more directly with new entrants (labour-intensive production, FDI dependent growth etc.) were particularly limited in efficiency growth.

From the discussion above, it comes that a country will be ready for EU entry if it succeeds to strengthen its political and economic relationships with the EU, and adapt the same institutional framework, already in the pre-accession period. The same holds if we consider benefits that an accession country may have from the integration. However, since accession preparation takes some time, and there may also be hold-up tendencies, in the meantime the private sector of an accession country anticipatory invests in EU-related investments, which increases economic dependence on the EU, and leaves the country with a costly option to abandon negotiations.

At the end of this part, before we turn to discuss the Western Balkans specificity, we would underline very insightful conclusions drawn from the model of Wallner (2003). The author concludes that applicants' costs of joining the EU change the welfare effect of membership, so that it can be eventually negative. As for the costs of joining the EU, the author lists a number of examples, ranging from large costs of compliance with environmental regulation to investments in EU safety and technical standards that are costly and make accession countries' products uncompetitive in alternative (lower-income) markets. There are a number of less visible irreversible costs related to trade specialisation, breaking up economic relationship with previous trade partners, premature privatisation of un-restructured domestic industries that allow EU investors to acquire the control of valuable assets at bargain prices.

If the EU acts strategically and in a selfish way, it will take advantage of the weaker bargaining position of the applicants and try to extract a rent by imposing entry requirements that will ensure benefits for the EU on the expense of the applicants. Commenting "all public declarations of common interests and charitable EU motivations", Wallner (2003: 880) said: "it is somewhat of a mystery how one can aggregate 15 selfish countries and arrive at an altruistic total".

This formally modelled behaviour seems more likely in future enlargements than it has been in previous ones. Previous enlargements left Europe with new instruments that can be effectively used in order to postpone new enlargements. There is also a stronger pressure for controlling costs that are to be borne by incumbent states. As far as the Western Balkans is concerned, things are looking in some ways the same, but in some important ways different. Among similarities, their transitional past and 
(near) future is highest on the list. Moreover, as we have seen, that distribution of enlargement benefits among old member states depends largely upon the strength of existing economic ties between each incumbent and perspective member state. For Western Balkans countries, Germany and Austria are the most important trade and investment partners, with Italy and Greece holding a way better position than in previous enlargements (Vachudova, 2014). Finally, relative to the size of the EU, Western Balkans countries are almost irrelevant economies. Although, it is true that even the fifth most massive round of enlargement brought into the EU economies of rather incomparable size, the overall importance of those two groups of countries is significantly different.

The most prominent difference between earlier and future enlargements are the benefits that in the latter case will come well above and beyond economic gains. Western Balkans is in desperate need for speeding up the democratisation process and settling down regional disputes (Elbasani, 2008; Vachudova, 2014). Because of this specificity, for Western Balkans the EU is probably still a one-way path to stability and prosperity. But there are also new challenges that may change the outcome of the whole project (Panagiotou, 2013). One should wait and see how future enlargements will fit into new cracks of Europe, id est North-South, and core-periphery collisions.

\subsection{Nominal and real convergence as alternative ways to assess preparedness to unification}

Theoretically, based on predictive power of (neo)classical (growth) model of diminishing returns, regional integration is expected to ensure growth convergence, since it enhances factor movements that will eventually come to equalisation of factors' productivity and rewards, namely relative factor prices, i.e. wages and profit will come into alignment (Barro et al., 1991).

Scientific evidence on preparedness of countries to join the European Monetary Union (EMU) is by no means scarce. A thorough review of earlier studies one can find in Koukoritakis and Michelis (2006), while more recent evidence is provided also in Marelli and Signorelli (2010), Bongardt et al. (2013) and Dauderstädt (2014), with novel research being more pessimistic then early assessments. It is expected that convergence issue draws more attention in cases of monetary integration since Maastricht criteria of nominal convergence are put as a formal barrier only to the more advance step into the EMU. However, it would be wrong to neglect importance of the convergence, especially real convergence, even if the EMU is considered short-term option for accession countries. Namely, if an accession country fails to converge with the rest of the Union, it will question long-term sustainability of the integration project. For example, Koukoritakis and Michelis (2006) tested whether ten Eastern European and Mediterranean 
countries from the fifth enlargement were ready to join the Eurozone based on a set of nominal and real convergence criteria. Their choice of indicators is especially interesting for our study. For nominal convergence, the full set of the Maastricht criteria was analysed, while real convergence was tested using real exchange rates and the real per capita GDP data. The authors employed co-integration and common trends techniques, using official data span that goes back as far as ten years from the year of entry, and found that the countries of interest partially converged with the two core EMU countries (France and Germany) in terms of monetary policy as well as economic structures. Full convergence is evidenced only in co-movements of inflation differentials, while the data showed no convergence at all in case of two fiscal variables, namely, deficit to GDP ratio and public debt to GDP ratio.

Real convergence becomes an important issue in our discussions as it captures longstanding benefits of lower-income countries to join the EU. Their ultimate wish is to have income level and living standards of the developed Western democracies. However, what is real convergence at all? What should converge and how can we measure it? By real convergence, opposite to nominal one, we mean that vital measures of economic performance and success moved or tend to move in direction that discrepancies (gaps) between two units (countries or regions) get decreasing or disappearing. What is appropriate to use in order to present economic success based on increase of productivity (rise in value added per hour of employee)? The best measurable candidate is real per capita (GDP) growth (controlled for the equality of income distribution), while some other more direct measures of welfare are worth considering, e.g. life expectancy, unemployment rate, social deprivation, calorie consumption, available living space etc. (Dauderstädt, 2014). From the technical (measurement) point, based on well-accepted literature, there are two basic indicators of convergence/divergence and consequently two concepts. We can either measure statistical dispersion of the chosen variable within the group of units, which is known as sigma convergence, or measure the rate of convergence based on speed at which units with lower initial value increase relative to units with higher initial value, known as beta convergence (Barro, 1991).

From the empirical point of view, there are no strong empirical records that regionally integrated countries outperform autarchic areas in terms of their potential to catch up with their better-performing peers. Further on, it seems that it does not even ensure real convergence between members of economic integration. There are a number of studies that investigate the convergence/divergence empirics within integrated Europe with overall result of earlier studies being inclined to existence of real convergence trend, though the estimates indicate various strengths of the catching-up process (for a review see Dauderstädt, 2014). Novel research that covers period after the global crisis not only contradicts previous results but also questions the above finding in the sense that the optimistic results now apply only temporarily. The growth in Southern Europe periphery not even failed to converge to that of the core, but also turned into full-blown economic recession. 
The distinction between nominal and real convergence is very important for the political economy. Nominal convergence, as defined in the Maastricht criteria for EMU, is mainly the interest of EMU, while real convergence captures the best hopes of accession countries. Much less stress in accession negotiations is put on real convergence since disappointing results in that manner will not put the entire integration project in danger and harm the interests of the club of existing members. Therefore, for the EMU, which imposes the rules on candidates, nominal convergence criteria look like 'right' instrumentarium to reach 'false' goal of real convergence, while for the candidate countries, the criteria may look like 'wrong' instrumentarium to reach a 'genuine and ultimate' goal. Thus, a conflict between nominal and real convergence is just a manifestation of dichotomy of interests of those two groups of countries.

An open dilemma for acceding countries is how much their commitment to nominal convergence criteria may go without sacrifices, i.e. output and employment losses (Rossi, 2004). It is a question of aligning stability to growth goals. From the very beginning, EMU have had a problem with initiating real convergence, probably because nominal convergence was put in the forefront of policy discussions, as the first and foremost goal. The vast experience of previous enlargements shows that real convergence is lagging behind nominal convergence. Moreover, Tykhonenko (2013) found that the fifth enlargement (CEECs) led to a variable-speed Europe of real convergence, while Bação et al. (2013) found that deterioration of key macroeconomic variables appeared after Portugal adapted common currency. Similarly, some argue (Kovačević, 2017) that persistent current account deficits for a large part of Southeast European periphery can be assigned to the policy being inconsistent with nominal rigidity of exchange rate (which ultimately lead to currency appreciation). Note that the early adoption of the euro was previously strongly recommended for new member states (Rostowski, 2006). Although more flexibility in nominal exchange rate as an alternative to rigid regimes (and common currency as well) is not uniformly accepted as a better option for current account deficits and weak growth (Begović and Kreso, 2017). Therefore, historical experience tells us that the success of the process of nominal convergence might be expected at the expense of real divergence among the member countries. For, nominal convergence, which is defined in the Maastricht Treaty as a set of requirements needed to be fulfilled by countries intending to join the EMU, requires clear stabilisation-oriented policy. In order to boost economic growth, improve the well-being of population, a new EU member should significantly increase public investments and speed up the restructuring of its economy and other structural reforms. These undertakings may be strongly infringed with the policy strictly oriented to financial (nominal) stabilisation. Thus, a rational path for an acceding country is to postpone EMU entry and work hard on tasks that will help undergo real convergence ( Facchini and Segnana, 2003; Rossi 2004). 


\section{Empirical data and analysis}

The analysis used data for 40 countries, 28 EU countries (Austria, Belgium, Bulgaria, Croatia, Cyprus, Czech Republic, Denmark, Estonia, Finland, France, Germany, Greece, Hungary, Ireland, Italy, Latvia, Lithuania, Luxembourg, Malta, the Netherlands, Poland, Portugal, Romania, Slovakia, Slovenia, Spain, Sweden, United Kingdom) and 12 countries that are not members of the European Union, but with a tendency to become a member (Serbia - candidate since 2012; Montenegro - candidate since 2010; Bosnia and Herzegovina - potential candidate since 2014; Macedonia - candidate since 2005; Albania - candidate since 2014; Moldova, Ukraine and Georgia - signed Association agreement with EU in 2014; Belarus, Azerbaijan and Armenia - Members of the Eurasian Economic Union; Switzerland - withdraw its Application for the Membership in 2016) in the period from 2000 to 2014. The variables used in the analysis have their starting point in the convergence criteria also, but they were primarily selected as the most important macroeconomic indicators that provide an insight into the level of the economic development of the countries surveyed. The analysis includes: Inflation rate expressed in percentage (HICP), GDP per capita (PPP, current international, \$); current account balance (share of GDP); real interest rate (in percentage); trade (export plus import as $\%$ of GDP); FDI net inflows (share of GDP); FDI net outflows (share of GDP); general government final (GGFCE) consumption expenditure (share of GDP); gross national expenditure (GNE) (share of GDP); final consumption expenditure (FCE) (share of GDP); gross savings (share of GDP); deposit interest rate (in \%); gross capital formation (GCF) as a share of GDP; long-term (LT) unemployment (share of total unemployment); merchandise trade (share of GDP); money and quasi money (M2) as a share of GDP.

The sources of the data are statistical database of the European Union (Eurostat) and the statistical database of the World Bank (World Bank Data). The essence of the analysis is to identify those variables that proved to be the most important indicators of successful membership in the European Union whose value reflects the possibility of enjoying all the benefits of membership.

Statistical analysis shows that the difference of mean values of inflation rate (HICP), final consumption expenditure, GDP per capita, gross national expenditure, gross capital formation, money and quasi money, deposit interest rate and foreign direct investment net outflows, between members and non-members of the EU are statistically significant (Table 1). The dataset presents average value for each country for the entire period. All the variables are expressed in percentage of GDP unless otherwise stated. 
Table 1: Difference of mean values for selected indicators

\begin{tabular}{|c|c|c|c|c|c|c|c|c|c|}
\hline \multirow{2}{*}{ Variable (in \%) } & \multicolumn{4}{|c|}{ Not member of EU } & \multicolumn{4}{|c|}{ Member of EU } & \multirow{2}{*}{$p$} \\
\hline & mean & SD & $\min$ & $\max$ & mean & SD & $\min$ & $\max$ & \\
\hline Inflation rate & 8.57 & 9.90 & 0.63 & 35.27 & 3.04 & 2.08 & 1.31 & 12.26 & 0.005 \\
\hline FCE & 89.27 & 17.36 & 56.06 & 113.38 & 76.24 & 7.59 & 50.77 & 87.88 & 0.013 \\
\hline GDP $p c(000 \$)$ & 11.26 & 11.32 & 3.32 & 46.18 & 29.03 & 12.74 & 12.26 & 76.32 & 0.000 \\
\hline GNE & 114.7 & 16.26 & 84.62 & 137.37 & 99.26 & 7.94 & 69.87 & 109.47 & 0.003 \\
\hline GCF & 25.95 & 4.36 & 20.40 & 34.25 & 23.13 & 3.17 & 17.01 & 30.34 & 0.027 \\
\hline M2 & 47.38 & 35.63 & 21.70 & 143.52 & 65.93 & 38.38 & 33.92 & 168.18 & 0.029 \\
\hline Deposit interest rate & 8.02 & 4.40 & 0.67 & 17.11 & 3.49 & 2.25 & 0.06 & 11.19 & 0.001 \\
\hline FDI, net outflows & 2.24 & 4.01 & 0.13 & 12.47 & 24.18 & 89.99 & 0.14 & 478.74 & 0.003 \\
\hline GGFCE & 16.63 & 4.78 & 10.12 & 23.55 & 19.53 & 3.30 & 8.07 & 25.60 & 0.056 \\
\hline LT unemployment & 52.39 & 28.50 & 5.54 & 86.41 & 41.00 & 12.40 & 16.95 & 62.57 & 0.226 \\
\hline Real interest rate & 6.07 & 6.72 & -10.65 & 15.57 & 5.95 & 9.81 & -1.07 & 51.70 & 0.083 \\
\hline Trade & 96.81 & 20.01 & 70.30 & 131.98 & 109.80 & 54.16 & 51.70 & 314.72 & 0.716 \\
\hline FDI, net inflow & 7.14 & 4.94 & 2.36 & 18.95 & 7.91 & 9.14 & 0.82 & 37.06 & 0.083 \\
\hline Gross savings & 19.37 & 10.41 & -0.64 & 37.33 & 21.28 & 4.55 & 12.87 & 29.56 & 0.552 \\
\hline Merchandise trade & 76.50 & 21.13 & 47.09 & 119.44 & 82.83 & 35.79 & 33.00 & 167.16 & 0.492 \\
\hline Current account & -6.12 & 11.79 & -25.92 & 20.93 & -1.43 & 4.81 & -8.55 & 7.96 & 0.206 \\
\hline
\end{tabular}

Source: Authors' calculations

Regression analysis is used to determine the intensity of the changes of the dependent-variable variable that is associated with changes in the independentvariable variables. Using the regression model, it is possible to quantify the relationship or association between the dependent and independent variables, in such a way that it can determine to what extent the change of the dependent (categorical) variable is caused by the change of the independent variable. Logistic regression enables testing the model for prediction of categorical outcomes with two or more categories. Binary logistic regression is used to investigate the dependence of a binary variable to one or more independent variables. The binary variable is usually taken to be the value of 0 or 1 . Independent variables can be numeric and categorical. These variables are called the predictor variables, because by using them the probability of a binary variable that receives value 1 is predicted. The aim of the application of the statistical methods described above is to identify variables that have the greatest impact on the change of the categorical variables (membership in the EU) through the univariate and multivariate regression analysis. Binary logistic regressions were done using SPSS (Version 19). 
The univariate binary regression analysis (Table 2) indicated that the membership in the EU is significantly affected by inflation rate. The odds ratio is 0.767 , which means that its increase by one percent decreases the chance for the country to become an EU member by $23.3 \%$.

Table 2: Summary of univariate and multivariate binary regression results

\begin{tabular}{|l|c|c|c|c|c|}
\hline \multirow{2}{*}{ Variable } & \multicolumn{2}{|c|}{ Univariate binary regression } & \multicolumn{2}{c|}{ Multivariate binary regression } \\
\cline { 2 - 6 } & Odds ratio & $p$ & Nagelkerke ${ }^{2}$ & Odds ratio & $p$ \\
\hline GGFCE & $1.213(1.002-1.468)$ & 0.047 & 0.152 & $1.422(1.011-1.999)$ & 0.043 \\
\hline GNE & $0.876(0.801-0.960)$ & 0.004 & 0.419 & $0.861(0.777-0.954)$ & 0.004 \\
\hline Inflation & $0.767(0.589-1.000)$ & 0.050 & 0.263 & & \\
\hline FCE & $0.901(0.833-0.976)$ & 0.010 & 0.311 & & \\
\hline GDP $p c$ & $1.211(1.068-1.373)$ & 0.003 & 0.550 & & \\
\hline GCF & $0.807(0.658-0.990)$ & 0.040 & 0.163 & & \\
\hline
\end{tabular}

Source: Authors' calculations

Based on results, gross domestic product per capita (GDP $p c$ ) has been confirmed as statistically significant for the EU membership. The odds ratio is 1.211 which means that its increase by $1,000 \$$, increases the chance for the country to become an EU member by $21.1 \%$. Final consumption expenditure has a significant impact on the EU membership. Final consumption expenditure (formerly total consumption) is the sum of household final consumption expenditure (private consumption) and general government final consumption. The odds ratio is 0.901 , which means that its increase by one (one \% of GDP) decreases the chance for a country to become an EU member by $9.9 \%$. Note that for those variables that are expressed as a share (\%) of GDP, the change in the value of a variable by one actually means the change equal to one percent of GDP value. Similar results are for the gross national expenditure. This measure is the widest of all tested consumption measures. Apart of private (household) final consumption and general government final consumption it includes also gross capital formation (formerly gross domestic investment). The odds ratio is 0.876 , which means that its increase by one decreases the chance for the country to become an EU member by $12.4 \%$. The odds ratio for general government final consumption expenditure (formerly general government consumption) is 1.213 , which means that its increase by value equal to one percent of GDP increases the chance for the country to become an EU member by $21.3 \%$. This measure of aggregate consumption includes all government current expenditures (goods and services purchased and compensation of employees) and excludes expenditures that go to government capital formation category. Thus, it is included in both final consumption expenditures and gross national expenditures. The membership is also significantly affected by gross capital formation. The 
odds ratio is 0.807 , which means that its increase by one decreases the chance for becoming an EU member by $19.3 \%$.

The next step in the analysis is running a multivariate logistic regression. We selected the variables that were previously indicated significant, based on univariate regressions. Using Wald's backward method (Table 4, Appendix), multivariate binary logistic regression shows that membership in the EU depends on general government final consumption expenditure (\% of GDP) and gross national expenditure (\% of GDP). The odds ratio for general government final consumption expenditure is 1.422 , which means that its increase by one percent of GDP value increases the chance for the country to become an EU member by $42.2 \%$. The odds ratio for gross national expenditure is 0.861 which means that its increase by one percent of GDP value decreases the chance for the country to become an EU member by $13.9 \%$.

Based on inputs from univariate and multivariate binary logistic regressions, we came up with a model of following specification:

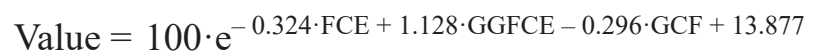

$$
\begin{aligned}
& \left(1+\mathrm{e}^{-0.324 \cdot \mathrm{FCE}+1.128 \cdot \mathrm{GGFCE}-0.296 \cdot \mathrm{GCF}+13.877}\right)
\end{aligned}
$$

The above model (1) provides values for all countries in the sample (not enclosed). The specification is set to classify the binary outputs as accurate as possible. Following the model above (1), it is possible to generate a special analytical tool known as Receiver Operating Characteristic (ROC) curve.

Figure 1: ROC curve (Y 2014)

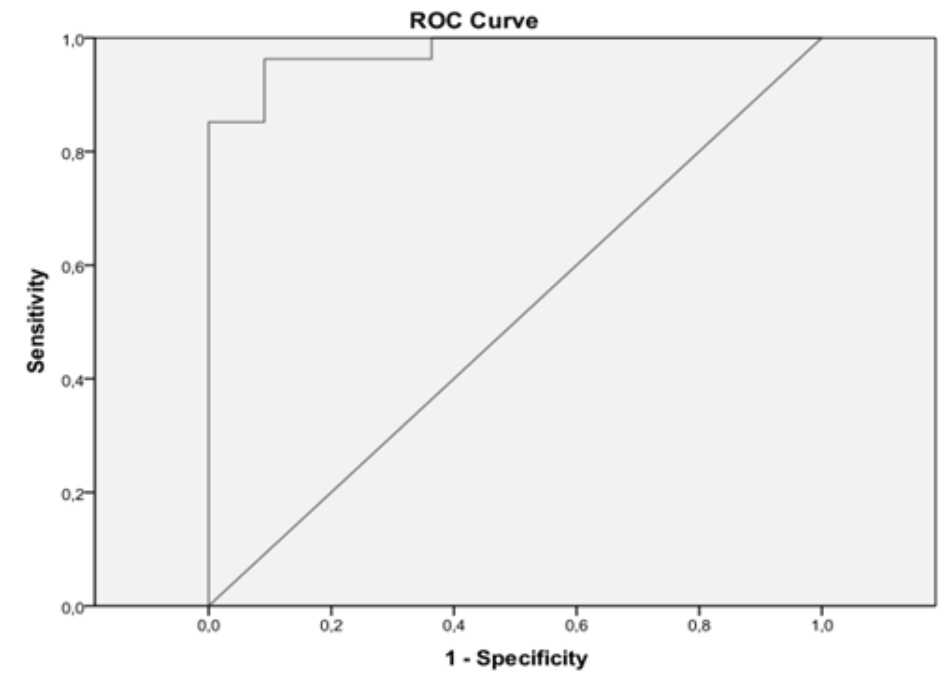

Source: Authors' calculations 
The ROC curve is a graphical representation of the sensitivity and specificity for each possible boundary score in the coordinate system, where the values of sensitivity (probability of detecting the presence of the correct attribute) are shown on the ordinate (y), and the abscissa (x) shows the values of specificity (probability of incorrect detection of the presence of the feature).

ROC curve shows that our model can be a reliable marker for the sake of distinguishing between EU member states and non-member states. Area under the curve can be as high as $0.976(\mathrm{p}<0.0005)$. Cut-off point was determined by tuning procedure so that the product of sensitivity and specificity is to be the largest one. For the year 2014 cut-off is calculated as 55, the sensitivity and specificity values are 0.963 and 0.909 respectively. This means that $96.3 \%$ of the EU member states have the values of our model greater than 55 , and $90.9 \%$ of non-members have the values of our model less than the 55. The model has rather good calibration (Hosmer-Lemeshov goodness of fit gives $\mathrm{p}=0.810$ ).

Table 3: Model characteristics during the period of analysis

\begin{tabular}{|c|c|c|c|c|c|}
\hline Year & Area & $p$ & Cut-off & Sensitivity & Specificity \\
\hline 2000 & 0.774 & 0.005 & 91 & 0.773 & 0.652 \\
\hline 2005 & 0.853 & $<0.0005$ & 35 & 0.960 & 0.733 \\
\hline 2010 & 0.875 & $<0.0005$ & 85 & 0.889 & 0.769 \\
\hline 2014 & 0.976 & $<0.0005$ & 55 & 0.963 & 0.909 \\
\hline
\end{tabular}

Source: Authors' calculations

Running the same model on the data for different years provides different parameters (e.g. cut-off points) and the model slightly loses its accurateness. It is expected, since the model is calibrated based on data from year 2014 (Table 3).

\section{Results and discussion}

By analysing 40 countries, all 28 EU countries and 12 countries aspiring to become its members, for the period of 14 years and the use of a large number of macroeconomic variables, which found its footing in the criteria of a common currency, and from them derived the convergence criteria, it is shown that some variables are statistically significant indicators of the membership in the European Union. The subsequently conducted univariate analysis indicated that the membership in the EU is significantly affected by inflation records. Some earlier empirical findings were strong in favour of importance of GDP figures (Šabotić et al., 2016), and it is not different in this study. The impact of GDP per capita has been 
confirmed as statistically significant for the EU membership. We have obtained similar results for final consumption expenditure, gross national expenditure, gross capital formation and general government final consumption expenditure. Following the univariate binary logistic analysis and separation of variables that affect the individual membership in the EU, a multivariate regression analysis was applied. Multivariate binary logistic regression shows that consumption expenditure variables have significant impact on the EU membership. Interestingly, it appears that a lower share of private (household) final consumption and a higher share of government final consumption in GDP increase the likelihood of a candidate to become a member of EU. Although we cannot be sure of the impact of domestic investment on chances to become a member, it seems that it is negative. It is hard to give a rationale for the observed regularities. One possible answer is that the increase in government spending was needed (for example during the preparatory phase) in order to strengthen institutional capacities for accession. As an alternative answer, it could be simply that the countries that initially formed EU, and entered EU in successive enlargements, largely had comparably higher government spending as a common economic feature.

The model based on ROC curve allows reasonably accurate classification of countries on member and non-member countries, and sorting of potential candidates with respect to achieved criteria. From economic point of view, that is a confirmation of importance of reaching a threshold defined in macro-economic indicators which have confirmed a statistically significant difference between members and non-members of the EU, and only then a country should become a full member of the wider community. Otherwise, it would be on the side-lines, without much benefit for itself and for the Union as well. The new variable which we created shows that for all new entrants it is very important to reach this level (cut-off) of 55, that is, to make their economic position strong already in preaccession process. That should help policy-makers to make adequate decisions in the present, which would contribute to achieving macroeconomic resilience in the future.

\section{Conclusion}

The European Union has been exposed to numerous challenges. Some of them were concerned to the question of very survival and possibility to grow. The fact that today we have the Union composed of 27 countries, with an intention of getting larger in the future, confirms the strength and power of the EU. There will be new problems for the EU and potential candidates in the future and therefore it is very important for all to strengthen their own capacities. This analysis can help to define priorities in developing the process for future members, in order to make the European Union even more prosperous. 
As above theoretical analysis shown, there are many advantages and disadvantages of regional integration. Depending on the balance between foreseen benefits and costs, countries should decide whether they want to become part of the European Union or want their further economic development to be based on the pre-existing institutional frameworks. The Western Balkan countries have recognised the regional integration as an optimal way to achieve their primary goal of economic prosperity. Despite the fact that every country faces specific challenges, this analysis is intended to find common macroeconomic, measurable indicators that would indicate commonality among members and non-members relative to economic achievements and structure.

Subsequently conducted univariate analysis has indicated that the membership in the EU is significantly affected by the GDP per capita. The impact of gross national expenditure and general government final consumption expenditure has been confirmed as statistically significant for the EU membership. Similar results are for final consumption expenditure, gross capital formation and inflation. Following the univariate binary logistic analysis and separation of variables that affect the individual membership in the EU, a multivariate regression analysis was applied. Multivariate binary logistic regression shows that gross national expenditure and general government final consumption have a significant impact on the EU membership. Such results should be understood as regularity based on past enlargements experiences, with limited guidance for perspective undertakings.

The process of obtaining a full membership in the European Union is typically lengthy, exhaustive and is not time-limited. The moment of obtaining full membership is conditioned by numerous factors, some of which are economic in nature, but the factors that are political in nature have got a huge role in the past. This primarily relates to the political will of the European Union member countries for granting additional enlargement of the Union.

However, the experience of the countries that have joined the European Union, as well as those who have given up monetary sovereignty and adopted the euro, indicates the importance of managing accession undertakings taking into account already achieved economic development, expressed through the selected macroeconomic indicators.

\section{References}

Bação, P., Portugal Duarte, A., Monteiro, R. (2013) "Portugal and the euro: past, present and what future?" In Marinković S., Rochhia, S. eds., Rethinking Europe after the economic crisis (pp. 67-82), Niš: Faculty of Economics.

Baldwin, E. R. (1997) "A review of theoretical developments on regional integration”. In Ngola, G, Collier, P., Greenaway, D. eds., Regional Integration 
and Trade Liberalization in Subsaharan Africa (pp. 24-88), London: MacMillan Press, doi: 10.1007/978-1-349-25636-5_2.

Baldwin, E. R., Venables, A. J. (1995) "Regional economic integration". In Grossman, G., Rogoff, K. eds., Handbook of International Economics, Vol. III (pp. 1597-1644), Amsterdam: Elsevier, doi: 10.1016/s1573-4404(05)80011-5.

Barro, J. R. (1991) "Economic growth in a cross section of countries", The Quarterly Journal of Economics, Vol. 106, No. 2, pp. 407-443, doi: 10.2307/2937943.

Barro, J. R. et al. (1991) "Convergence across States and Regions”, Brookings Papers on Economic Activity, Vol. 1991, No. 1, pp. 107-182, doi: 10.2307/2534639.

Begović, S., Kreso, S. (2017) The adverse effect of real effective exchange rates change on trade balance in European transition countries", Proceedings of Rijeka Faculty of Economics: Journal of Economics and Business, Vol. 35, No. 2, pp. 277-299, doi: 10.18045/zbefri.2017.2.277.

Belke, A., Hebler, M. (2000) "EU enlargement and labour markets in the CEECs", Intereconomics, Vol. 35, No. 5, pp. 219-230, doi: 10.1007/bf02930138.

Bongardt, A. et al. (2013) "Convergence in the EU", Intereconomics, Vol. 48, No. 2, pp. 72-92, doi: 10.1007/s10272-013-0448-9.

Breuss, F. (2002) "Benefits and dangers of EU enlargement", Empirica, Vol. 29, No. 3, pp. 245-274, doi: 10.1023/a:1020255826824.

Buch, M. C. (1999) "Capital mobility and EU enlargement", Weltwirtschaftliches Archiv, Vol. 135, No. 4, pp. 629-656, doi: 10.1007/bf02707388.

Buch, M. C., Piazolo, D. (2001) "Capital and trade flows in Europe and the impact of enlargement", Economic Systems, Vol. 25, No. 3, pp. 183-214, doi: 10.1016/ s0939-3625(01)00019-x.

Crozet, M., Soubeyran, P. K. (2004) "EU enlargement and the internal geography of countries", Journal of Comparative Economics, Vol. 32, No. 2, pp. 265-279, doi: 10.1016/j.jce.2004.02.009.

Csaba László (2001) "Double talk: The political economy of eastward enlargement of the EU", Intereconomics, Vol. 36, No. 5, pp. 235-243, doi: 10.1007/bf02928977.

Curran, L., Zignago, S. (2012) "EU enlargement and the evolution of European production networks", Research in International Business and Finance, Vol. 26, No. 2, pp. 240-257, doi: 10.1016/j.ribaf.2011.12.002.

Dauderstädt, M. (2014) "Convergence in crisis: European integration in jeopardy", International Policy Analysis, Berlin: Friedrich Ebert Stiftung.

Dvoř́k, T., Podpiera, R. (2006) "European Union enlargement and equity markets in accession countries", Emerging Markets Review, Vol. 7, No. 2, pp. 129-146, doi: 10.1016/j.ememar.2005.09.009.

Elbasani, A. (2008) "EU enlargement in the Western Balkans: strategies of borrowing and inventing", Journal of Southern Europe and the Balkans, Vol. 10, No. 3, pp. 293-307, doi: 10.1080/14613190802493600. 
Elsner, B. (2013) "Emigration and wages: The EU enlargement experiment", Journal of International Economics, Vol. 91, No. 1, pp. 154-163, doi: 10.1016/j. jinteco.2013.06.002.

Facchini, G., Segnana, M. L. (2003) "Growth at the EU periphery: the next enlargement", The Quarterly Review of Economics and Finance, Vol. 43, No. 5, pp. 827-862, doi: 10.1016/s1062-9769(03)00051-6.

Garmel, K., Maliar, L., Maliar, S. (2008) "EU eastern enlargement and foreign investment: Implications from a neoclassical growth model", Journal of Comparative Economics, Vol. 36, No. 2, pp. 307-325, doi: 10.1016/j.jce.2007. 04.003 .

Halkos, E. G., Tzeremes, G. N. (2009) "Economic efficiency and growth in the EU enlargement", Journal of Policy Modeling, Vol. 31, No. 6, pp. 847-862, doi: 10.1016/j.jpolmod.2009.08.003.

Heinemann, F. (2003) "The political economy of EU enlargement and the Treaty of Nice", European Journal of Political Economy, Vol. 19, No. 1, pp. 17-31, doi: 10.1016/s0176-2680(02)00127-1.

Hildebrandt, A., Wörz, J. (2005) "Patterns of industrial specialization and concentration in CEECs: Theoretical explanations and their empirical relevance". In Welfens, P. J., Wziatek-Kubiak, A., eds., Structural change and exchange rate dynamics (pp. 119-146), Berlin-Heidelberg: Springer, doi: 10.1007/3-540-28526-1_10.

Kandogan, Y. (2000) "Political economy of eastern enlargement of the European Union: Budgetary costs and reforms in voting rules", European Journal of Political Economy, Vol. 16, No. 4, pp. 685-705, doi: 10.1016/s0176-2680(00) 00021-5.

Kohler, W. (2004) "Eastern enlargement of the EU: a comprehensive welfare assessment", Journal of Policy Modeling, Vol. 26, No. 7, pp. 865-888, doi: 10.1016/j.jpolmod.2004.08.006.

Koukouritakis, M., Michelis, L. (2006) "EU enlargement and the Eurozone: Convergence or divergence?" The Journal of Economic Asymmetries, Vol. 3, No. 1, pp. 39-58, doi: 10.1016/j.jeca.2006.01.003.

Kovačević, R. (2017) "Current account determinants in Southeast European (SEE) countries: panel approach", Proceedings of Rijeka Faculty of Economics: Journal of Economics and Business, Vol. 35, No. 2, pp. 391-424, doi: 10.18045/ zbefri.2017.2.391.

Krugman, P. (1980) "Scale economies, product differentiation, and the pattern of trade", The American Economic Review, Vol. 7, No. 5, pp. 950-959.

Marelli, E., Signorelli, M. (2010) "Institutional, nominal and real convergence in Europe", Banks and Bank Systems, Vol. 5, No. 2, pp. 140-155.

Matthews, A. (2003) Regional Integration and Food Security in Developing Countries, Rome: Food and Agriculture Organization of the United Nations. 
Maurel, M. (2004) "Current account constraint as a barrier to international trade: the evidence from the European enlargement process?", Economic Systems, Vol. 28, No. 3, pp. 301-317, doi: 10.1016/j.ecosys.2004.03.007.

Nahius, R. (2004) "One size fits all? Accession to the internal market; and industrylevel assessment of EU enlargement", Journal of Policy Modeling, Vol. 26, No. 5, pp. 571-586, doi: 10.1016/s0161-8938(04)00060-2.

Neueder, F. (2003) "Costs and benefits of EU enlargement", Intereconomics, Vol. 38, No. 5, pp. 190-195, doi: 10.1007/bf03031706.

Panagiotou, R. (2013) "The Greek crisis as a crisis of EU enlargement: how will the Western Balkans be affected?", Southeast European and Black Sea Studies, Vol. 13, No. 1, pp. 89-104, doi: 10.1080/14683857.2013.773178.

Rose, A. (2000) "One money, one market: the effect of common currencies on trade", Economic Policy, Vol. 15, No. 30, pp. 8-45, doi: 10.1111/1468-0327. 00056.

Rossi, S. (2004) "The enlargement of the euro area: what lessons can be learned from EMU?", Journal of Asian Economics, Vol. 14, No. 6, pp. 947-970, doi: 10.1016/j.asieco.2003.08.001.

Rostowski, J. (2006) "When should the new member states join the EMU?", In Dabrowski, M., Rostowski, J. eds., The Eastern Enlargement of the Eurozone (pp. 1-14), Boston: Springer, doi: 10.1007/0-387-25766-7_1.

Šabotić, Z., Marinković, S., Banković, D. (2016) "Quantifying the economic parameters as indicators of optimal moment of Serbia's accession to the EU", Teme, Vol. 40, No. 1, pp. 187-202.

Tykhonenko, A. (2013) "The impact of the global economic crisis on the catchingup process". In Marinković S., Rochhia, S. eds., Rethinking Europe after the economic crisis (pp. 9-25), Niš: Faculty of Economics.

Vachudova, M. A. (2014) "EU leverage and national interests in the Balkans: The puzzles of enlargement ten years on", Journal of Common Market Studies, Vol. 52, No. 1, pp. 122-138, doi: 10.1111/jcms. 12081.

Wallner, K. (2003) "Specific investments and the EU enlargement", Journal of Public Economics, Vol. 87, No. 5-6, pp. 867-882, doi: 10.1016/s0047-2727(01)00159-1. 


\title{
Proširenje EU: Je li ekonomija regionalne integracije važna?
}

\author{
Srđan Marinković ${ }^{1}$, Zenaida Šabotić ${ }^{2}$, Dragić Banković ${ }^{3}$
}

\begin{abstract}
Sažetak
Za stabilnost i napredak EU-a i potencijalnih zemalja članica, važno je procijeniti najbolje vrijeme za novo proširenje. $U$ ovom smo radu testirali brojne makroekonomske i makrofinancijske varijable kako bismo provjerili jesu li brojne zemlje bile spremne za ulazak u EU i jesu li zemlje kandidatkinje spremne. Neke varijable predstavljaju kriterije nominalne konvergencije definirane $u$ Maastrichtskom ugovoru, dok ostale varijable pokazuju razinu stvarne konvergencije. Univarijatna analiza pokazala je da članstvo u EU značajno utječe na BDP po glavi stanovnika, opće izdatke države za finalnu potrošnju, izdatke za finalnu potrošnju, bruto investicije, bruto nacionalne izdatke i inflaciju. Slijedeći univarijatnu binarnu logističku analizu i razdvajanje varijabli koje utječu na pojedinačno članstvo u EU, primijenjena je multivarijatna regresijska analiza. Multivarijatna binarna logistička regresija potvrdila je značaj općih izdataka države za finalnu potrošnju i bruto investicija. Analiza je ukazala na važnost odabira vremena pristupanja $u$ pogledu ostvarenog gospodarskog razvoja, iskazanog kroz odabrane makroekonomske pokazatelje. Štoviše, čini se da je popis testiranih ekonomskih kriterija, u najboljem slučaju, imao sekundarnu važnost u prošlim europskim proširenjima.
\end{abstract}

Ključne riječi: makroekonomski pokazatelji, Europska unija, regionalna integracija, kriteriji konvergencije

JEL klasifikacija: F15, F16, F45, G15

${ }^{1}$ Redoviti profesor, Sveučilište u Nišu, Ekonomski fakultet, Trg kralja Aleksandra Ujedinitelja 11, 18000 Nǐs, Srbija. Znanstveni interes: bankarstvo i financije, međunarodne financije, makroekonomija.Tel.: +38162216068.E-mail:srdjan.marinkovic@eknfak.ni.ac.rs.

2 Asistent, Državno sveučilište u Novom Pazaru, Odjel za ekonomske znanosti, Vuka Karadžića bb, 36300 Novi Pazar, Srbija. Znanstveni interes: statistika i ekonometrija, financije. Telefon: +38120337669.E-mail: zenaida.sabotic@gmail.com.

${ }^{3}$ Redoviti profesor, Državno sveučilište u Novom Pazaru, Odjel za matematičke znanosti, Vuka Karadžića bb, 36300 Novi Pazar, Srbija. Znanstveni interes: teorijska i primjenjena matematika.Tel.: +38120337669.E-mail:dragic.bankovic@gmail.com. 


\section{Appendix}
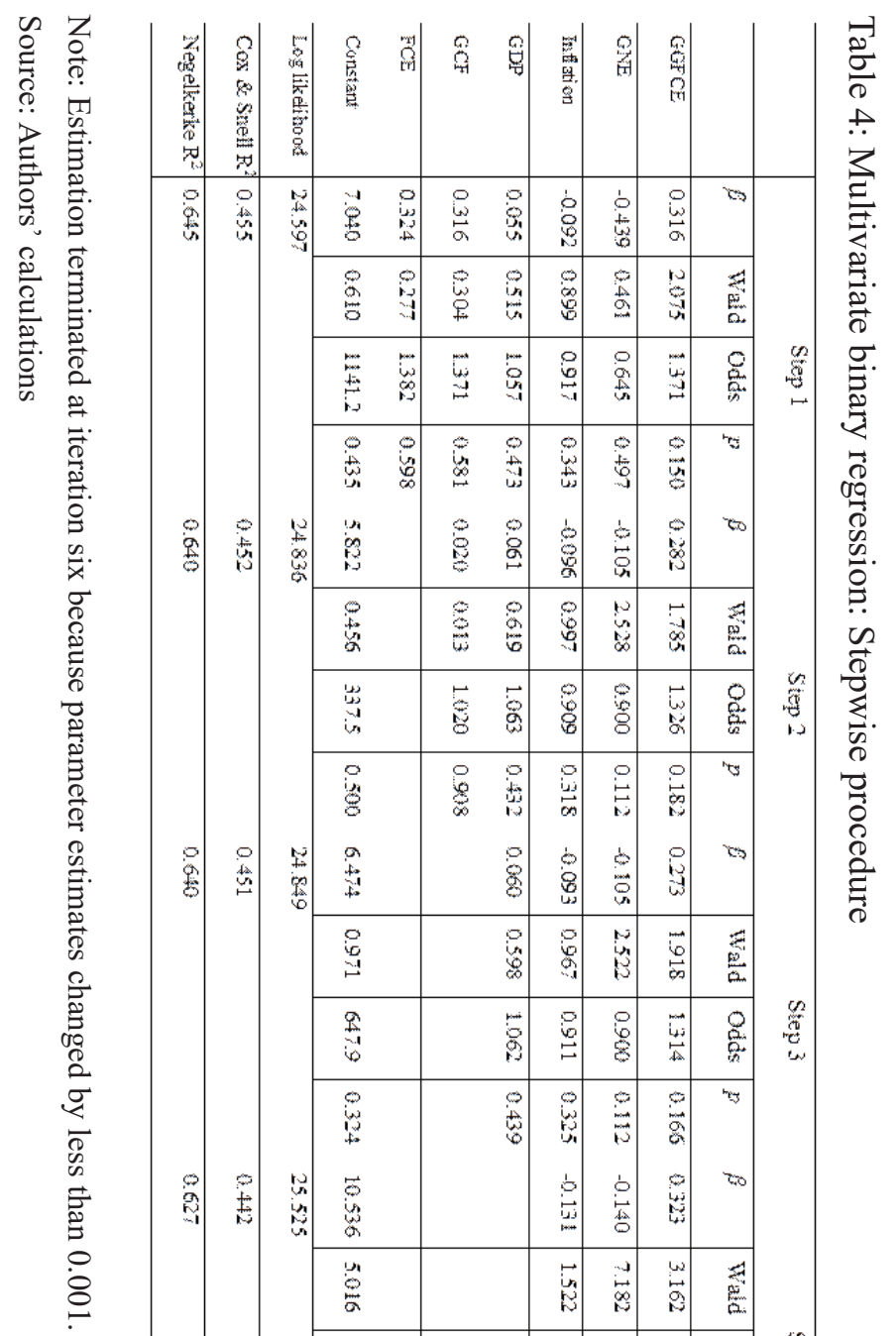